\author{
Марко Трајковић \\ Нии - Србија \\ e-mail: marko.trajkovic1989@gmail.com
}

\title{
ХРИШЋАНСКО ПРИЈАТЕЉСТВО КРОЗ ПРИЗМУ ПОСЛАНИЦЕ ФИЛИПЉАНИМА И МОГУЋНОСТ ПЕДАГОШКЕ ПРИМЕНЕ У ВЕРСКОЈ НАСТАВИ
}

\begin{abstract}
Апстракт: У овом раду сагледавамо хришћанско схватање пријательтва на примеру Посланице Филипьанима апостола Павла. Појам пријатељство Павле не користи у свом обраћању, али је његова веза са хришћанима у Филипима и те како пријатељька. Њихов однос превазилази пријатељство у класичном поимању, већ је та веза много снажнија јер је утемељена у љубави ка Богу. Поред Посланице Филипљанима, анализиран део Посланице Коринћанима поткрепьује наведену тврдюу. Такође, у раду ћемо указати и на могућности педагошке примене хришћанског концепта пријатељства на часовима Верске наставе. Пријатељство је важна тема за деиу у школском узрасту, а особености хришћанског поимања пријатељства намећу потребу бављења овом темом на Веронауци.

Кључне речи: апостол Павле, пријательтво, Посланича Филипљанима, Верска настава.
\end{abstract}

\section{Увод}

Апостол Павле, као један од најплоднијих новозаветних писаца, може на више места бити тумачен у контексту пријатељства. Ипак, Посланица Филипљанима је посебно илустративна у овом погледу, и на њој ће бити посебан фокус у процесу сагледавања хришћанског пријатељства. Осврт на један део Прве посланице Коринћанима представља додатак, који ће нам помоћи у том сагледавању. Истраживање ће бити усмерено у правцу могућег превазилажења временске дистанце (антика-савременост), када је реч о хришћанском схватању пријатељства. То ће се одвијати кроз истраживање хришћанског пријатељства, али и кроз компарирање савременог и Павловог схватања пријатељства и кроз указивање на могућности обраде теме пријатељства на часовима Верске наставе.

\section{1. Мотив пријатељства код апостола Павла на примеру Посланице Филипљанима}

У жељи да одговоримо на питање хришћанског поимања пријатељства, кроз реч и дело апостола Павла, посветићемо пажњу његовој Посланици Филипљанима. Два важна аспекта пријатељства код Павла чине: помоћ пријатељу у невољи и дистанцирање себе од непријатеља („злих посленика“ Фил 3, 2), и они су, поред Посланице Филипљанима, уочљиви у Посланицама Коринћанима и у Посланици Галатима. ${ }^{1}$ Такође, Посланица Филимону може бити разматрана у контексту пријатељства будући да је

1 Winter 2016, 200. 
прожета снажним пријатељским тоном. Постоји, дакле, више места која садрже мотиве пријатељства код Павла, али се и поред тога бављење пријатељством у Павловом литералном опусу може чинити спорним будући да он не употребљава реч пријатељство, нити га експлицитно одређује. Појам пријатељство ( је појам пријатељ (

Међутим, одабир поменуте посланице условљен је чињеницом да је однос Павла и Цркве у Филипима био посебно присан, због чега је ово његова „најличнија и најосећајнија посланица.“4 Хелерман истиче да садржај и форма посланице указују да је то пријатељско писмо. ${ }^{5}$ Поред тога, бројни аутори истичу да Павлов говор о заједничарењу, једнодушности и једномислености, јасно упућује на Павлову употребу пријатељских мотива и чини посланицу најексплицитнијим говором о пријатељству. ${ }^{6}$

Иако не употребљава овај појам, имплицитни изрази пријатељства код Павла

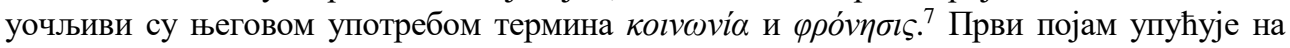

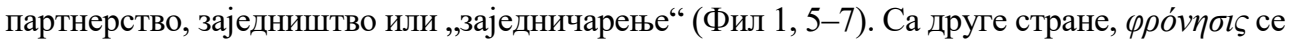
односи на исто мишљење, разумевање - „да исту љубав имате, једнодушни, једномислени." ${ }^{8}$ Поред ових појмова осврнућемо се на још неке термине у посланици

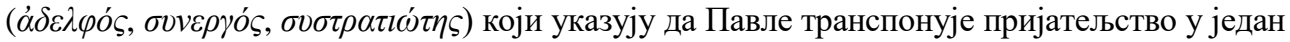
виши степен међусобног опхођења. ${ }^{9}$ Напослетку, не бисмо се смели ограничити само на она места која лексички корелирају с појмом који истражујемо, јер као што присуство термина не упућује нужно на хришћанску традицију пријатељства (нпр. „посла капетан к Њему пријатеље“ Лк 7, 6), тако и одсуство термина у Посланици Филипљанима не имплицира непостојање концепта пријатељства. ${ }^{10}$

Поједини аутори указују на сличност у схватању пријатељства између Павла и Аристотела, ${ }^{11}$ наглашава се његова блискост са стоицизмом ${ }^{12}$ и појединим античким мислиоцима, ${ }^{13}$ као и могући утицај јудаизма ${ }^{14}$ на његово схватање пријатељства. Павле је потекао из јеврејске породице и од раног узраста је био васпитаван у јудејској традицији од стране истакнутог рабина Гамалила. ${ }^{15}$ Међутим, он је био и римски грађанин и човек

2 У Јак 4, 4 појам пријатељство има негативну конотацију. Пријатељство са светом које Јаков помиње подразумева прихватање световних вредносних образаца који су у супротности са Богом, тако да овако схваћено пријатељство јесте непријатељство према Богу. Johnson 2004, 216.

3 Видети: Лк 7, 6; 11, 5, 6, 8; 12, 4; 14, 10, 12; 15, 6, 9, 29; 16, 9; 21, 16. Јн 3, 29; 11, 11; 15, 13-15; 19 , 12. Наведена су нека од места на којима сусрећемо појам пријатељ (фі́ $\lambda \circ \varsigma)$.

4 Каравидопулос 2009, 214.

5 Hellerman 2009, 20.

6 Winter 2016, 199.

7 Детаљније о овоме видети: Briones 2019.

8 Фил $2,2$.

9 Према неким мишљењима одсуство појма пријатељство условљено је управо тиме што је он за Павла био превише антропоцентричан. Видети: Reumann 1996, 105.

10 Winter 2016, 193.

11 О сличности Павла и Аристотела у погледу пријатељства видети: Briones 2019.

12 Драгутиновић наводи да је блискост са стоичком традицијом видљива на пољу етике, антропологије и слободе, истичући да Павле философским појмовима даје еклисиолошку димензију. Драгутиновић 2011, 300. Савковић истиче да се Павле у посланици Римљанима користио стоичким методама и концептима не би ли учинио блиским и разумљивим своје учење. Савковић 2019, 6.

13 У овом контексту често се помиње Сенека, који је имао значајне мисли о пријатељству, а које су можда биле блиске Павлу. О сличностима у погледу неких конститутивних аспеката пријатељства видети: de Silva 2017, 150-178.

14 Детаљније о јудаистичкој традицији пријатељства видети: Goshen-Gottstein, 2020.

15 Haacker 2003, 21. 
који није био имун на широк спектар утицаја којима је био изложен. Вероватно је да су сви поменути погледи били Павлу познати, чак је могуће да су имали утицаја на Павлово схватање пријатељства. Међутим, упркос свим поменутим утицајима, Павле је себе сагледавао „превасходно у светлу свог односа са Исусом Христом, тако да је шта год да је из ових других извора могао добити, свест о проналаску новог усмерења на путу за Дамаск заувек остала преовлађујућа његовом мишљу." ${ }^{16}$ Стога ћемо се даље у раду фокусирати на хришћанске аспекте пријатељства код Павла, на примеру његове Посланице Филипљанима.

\section{1. Експлицитни изрази пријатељства у Посланици Филипљанима}

Посланица Филипљанима дотиче се више ствари, али „главни циљ посланице био је израз љубави и захвалности Филипљанима, а истовремено и њихова похвала због искрене и нелицемерне верности вери. “17 Наиме, када је након свог трећег мисионарског путовања, Павле у Јерусалиму оптужен за одступање од вере, провео је две године тамничења у Кесарији, након чега је пребачен у Рим где проводи још две године у кућном притвору. По свом најистакнутијем представнику, Епафродиту, Филипљани му, као осведочени пријатељи, шаљу новчану помоћ и доказују да су „простосрдачни и искрено верујући хришћани.“"18

Међу Филипљанима је пре конвертитства владао прихватајући (у ужем породичном смислу) и компетитивни (у ширем друштвеном смислу) образац социјалног опхођења, тако да је Павле тежио да укине овакву праксу и развије концепте братства и пријатељства међу свим филипљанским хришћанима. ${ }^{19}$ Због тога их позива да се угледају на Христа (Фил 2, 5-11) и да се не старају „свако за своје, него свако и за оно што је других.“20 Однос апостола са Тимотејем и Епафродитом значајан је јер пружа практичан увид у поменуто братско и пријатељско опхођење међу хришћанима.

Павле изражава наду да ће сам посетити Филипљане, но док до тога не дође он намерава да пошаље Тимотеја са жељом да чује о Филипљанима и да се обрадује сазнањима о њима. Тимотеј је веома важан, не само као спона у односу Павла и Филипљана, већ као неко ко послушношћу исказује пријатељски став према Павлу и филипљанским хришћанима, прихватајући се наметнутог задатка на добробит Филипљана. Тимотеј „не тражи своје“ већ оно што је Христа Исуса (Фил 2, 21), и управо због тога је он, за разлику од „свих“, спреман да поднесе пријатељски наметнуту дужност (жртву). Вероватно да други сарадници апостола Павла, услед личне слабости, нису могли да се прихвате овог послушања. ${ }^{21}$ Павле, правећи компарацију између Тимотеја и њих, поучава хришћане да ништа не раде „за празну славу““22 Тимотеј, дакле, за Павла није пуки извршилац поверене курирске дужности, већ истинска парадигма хришћанина који жртвује себе за добротит ближњег. То је разлог због кога га Павле шаље, јер је уверен да нико тако верно неће дејствовати у духу Апостола као он. ${ }^{23}$

16 Дрејн 2004, 366.

17 Аверкије 2005, 259.

18 Теофан $2008,11$.

19 Hellerman 2009, 20.

20 Фил $2,4$.

21 Hansen 2009, 195.

22 Фил 2, 3.

23 Теофан 2008, 75. 
Међутим, док не дође тренутак да им пошаље Тимотеја, он им шаље натраг Епафродита, по свему судећи једног од значајнијих представника филипљанске Цркве, који се није ништа мање пријатељски жртвовао да би донео помоћ Павлу. Павле се радује помоћи, не зато што му је преко потребна, „не због оскудице“ 24 , већ због љубави и пријатељског старања Филипљана. Тиме он показује да пријатељство са Филипљанима није из користољубља нити има материјалну позадину, ${ }^{25}$ због чега и истиче да не тражи дар, „него тражим плода који се множи на корист вашу.“26

Епафродита Павле назива братом, сатрудником и саборцем, а користећи присвојну заменицу (,брата и сатрудника и саборца мојега“ Фил 2, 25) апостол наглашава и личну приврженост коју осећа према њему. ${ }^{27}$ Употребом овакве реторике и атрибута Павле жели да апострофира хришћански етос међусобног опхођења, који је у знатној мери другачији од онога што је било обележје живота грађана Филипа пре примања хришћанства.

Хришћани нису позвани да у међусобном односу остварују некакав општи идеал пријатељства, типичан за антички или савремени секуларни свет, него да међусобно буду

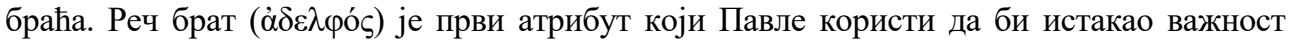
оваквог опхођења, као једног вишег вида пријатељства. Његов братски однос с Епафродитом датира вероватно још од прве посете Филипљанима и он га назива братом због истрајности у раду за Христа и јеванђеље. ${ }^{28}$ Називајући га даље сатрудником

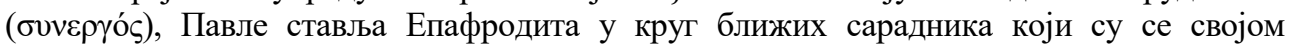
залагањем и пожртвованошћу (,Јер се за дјело Христово изложи до смрти...“ Фил 2, 30) истицали у ширењу јеванђеља. ${ }^{29}$ Епафродит је, као и Тимотеј, заједно са Павлом у служби царства Божијег, ${ }^{30}$ њихово дело је позив и осталим хришћанима да се исто владају. Напослетку, истрајавање у „заједничарењу“ представљало је не само духовни већ и изузетан телесни изазов и борбу са самим собом и хришћанском опозицијом, те је у том

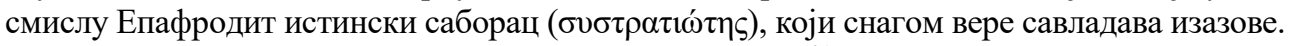

У Филипима су живели римски ратни ветерани, ${ }^{31}$ односно град је био „насеобина римска.“32 Павле жели да нова хришћанска заједница напусти пређашње обрасце међусобног опхођења и да чине ,један другога већим од себе.“33 То је Павлова визија Цркве, а горе поменути атрибути су кључни у изградњи такве заједнице. У том смислу термин пријатељство за њега је недовољно ,јак“ јер су Павле и хришћани у категоријама есхатона. Црква је за Павла породица и место где не владају пријатељски односи у класичном смислу, већ релације међу људима имају карактер сличан родбинским везама. Такво (христолошко) схватање живота оставља дубок траг на сваки однос, па и на пријатељство, које сагледано у христолошком кључу добија снажнији карактер.

Павле у раду на изградњи оваквих односа међу хришћанима има помоћнике, Тимотеја и Епафродита у којима види исте врлине које је имао и сам Христос, и зато их шаље Филипљанима са жељом да се и они усаврше. ${ }^{34}$ Тимотеј се одликује хришћанским

24 Фил 4, 11.

25 Berry 1996, 114.

26 Фил 4, 17.

27 Hansen 2009, 201.

28 Martin 1991, 103.

29 Hansen 2009, 202.

30 Martin 1980, 120.

31 Hawthorne and Martin 2004, XXXV; Hartog 2010, 477.

32 Дап 16, 12.

33 Фил $2,3$.

34 Hansen 2009, 192. 
алтруизмом, док је Епафродит по угледу на Христа узео „обличје слуге“ и умало страдао за другога. ${ }^{35}$ Они су сарадници апостола, али су се својим делима показали и као његови осведочени пријатељи. Павле не употребљава овај термин, али он кроз поменуте атрибуте са Филипљанима гради једну много чвршћу пријатељску везу.

\section{2. Имплицитни изрази пријатељства у Посланици Филипљанима}

Да бисмо увидели шта чини поменуту снагу хришћанског пријатељства, сагледаћемо га и у односу на класични концепт пријатељства. Тиме ћемо уочити сличности, разлике и особеност хришћанског концепта пријатељства.

Световно пријатељство садржи у себи већи број конституената, као што су наклоност, поверење, искреност, оданост и сл. Ипак, оно што чини пријатељство у суштинском смислу можемо свести на три аспекта: реципрочност односа, лични однос чест контакт и блискост. ${ }^{36}$ Остали нису мање важни, али су они, у извесном смислу, синоними уткани у три претходно набројана појма.

Реципроцитет односа. Реципрочност као интегрални фактор пријатељства присутан је још у антици, ${ }^{37}$ а да је тако и у савременом поимању закључујемо из речи С. Крњајића који наводи да „два појединца могу рећи да су у пријатељском односу само ако су наклоност и/или поштовање које они изражавају један према другом реципрочни.““38 Реципрочност односа подразумева једнакост у општењу, то јест позицију у којој ниједан актер пријатељског односа нема доминантну, ауторитарну позицију, као нпр. у односу родитељ-дете.

Апостол Павле је, као човек који је приволео Филипљане Христу, био много надахнутији и поученији у вери, али он свој ауторитет не гради узносећи се над ученицима и верницима. Већ у првом обраћању каже: „Павле и Тимотеј, слуге Исуса Христа.“39 Чинећи тако, Павле се изједначава не само са Тимотејем, него и са свим Филипљанима, јер им се обраћа „као равнима себи, не истичући своје учитељско достојанство.“40

Још један еклатантан пример реципрочности односа са верницима из Филипа јесте када Павле говори о „достизању у васкрсење мртвих.““1 Упркос свим подвизима које је постигао, он не сматра себе достојнијим од осталих верника већ истиче, још не мислим да сам достигао.“42 Хришћанинов пут најдужи је од свих путева, ${ }^{43}$ и Павле личним примером подстиче хришћане да заједно трче „према циљу награде небеског призвања.“44 Он то чини не као савршен, већ као једнак њима. Вероватно су ови и слични примери разлог што поједини аутори наглашавају снажан реципрочан тон у реторици текста Посланице Филипљанима. ${ }^{45}$

\section{5 Исто.}

36 Ову тврдњу, између осталог, поткрепљује и одређење по коме се пријатељство развија само између поједине деце и оно се огледа у јачем другарству, у жељи деце да заједно проводе време, да измењују међусобно мисли и поверавају једно другом своје тајне. Теодосић 1967, 249.

37 „пријатељство је једнакост.“ Аристотел, 1157б.

38 Крњајић 1990, 79.

39 Тимотеј је у 1 Тим 1,2 означен као „прави син у вери“, у Кол 1,1 је „брат Тимотеј“, у Фил 1,1 је, као и Павле, назван слугом, чиме је изражен реципроцитет односа.

40 Теофан 2008, 16.

41 Фил $3,11$.

42 Исто 3,13

43 Поповић 1986, 65.

44 Фил 3, 14.

45 Winter 2016, 200. 
Лични контакт. Интензивни лични контакти између пријатеља подразумевају се у контексту неговања пријатељства. Међутим, односи између Павла и Цркве у Филипима били су крајње ограничени, што због његовог сужањства, што због недостатка средстава комуникације оног доба. Међутим, и тај мали број сусрета није ставио на тест пријатељство Павла и Филипљана. У контексту одржања личних веза посланица има велики значај јер посланице као такве нису служиле за приватну лектиру, већ за јавно литургијско читање, читање на сабрању, чиме су целокупне хришћанске заједнице биле реципијенти посланица. ${ }^{46}$ Павле је дакле кроз своје писање одржавао „лични“ контакт са читавом заједницом, његове речи су живеле у срцима људи, који су увек изнова кроз њих осећали његову присутност, љубав и старање за њихов раст у Христу.

Штавише, апостол се у једном делу обраћа директно двема женама које су имале несагласје у вери у односу на све Филипљане. ${ }^{47}$ Павле пред целом филипљанском Црквом позива Еводију и Синтихију да једно мисле у Господу и још позива у помоћ јаче(г) у вери да помогну сестрама, не би ли очували јединство унутар филипљанске Цркве. Старао се, дакле, да и лични односи хришћана буду достојни њиховог призвања.

Блискост. Синтагма „близак пријатељ“ најчешће не упућује на физичку близину, колико блискост у виду вредности, идеја, поверења, слободе у комуникацији и сл., али је у очувању блискости свакако неопходна и физичка близина. Међутим, Посланица Филипљанима показује да, уколико је идеја око које се људи окупљају довољно снажна, она може очувати блискост и када физички контакт изостаје.

Филипљанска Црква показала се најревноснијом и најоданијом према свом оснивачу, а апостол је њима узвраћао истом оваквом узајамном љубављу. ${ }^{48}$ Истина коју је Павле донео Филипљанима била је толико снажна да је чинила темељ њиховог пријатељства, који није било лако пољуљати. Исус Христос је био њихов стожер, он их је свезао у заједничким стремљењима ка њему и на том путу су истрајавали. Христолошка љубав их је чинила блискима, али су они додали још један важан елемент хришћанског живота да би „подгревали“ духовну близину. Наравно, реч је о узајамној молитви. Павле захваљује Богу кад се сети њих (Фил 1,3$)$ и сваку помисао претвара у молитву за њихово узрастање у љубави (Фил 1, 9), што је „права еванђељска брига о људима.“49 Он се радује њиховом заједничарењу у јеванђељу, односно труду који улажу у служењу и саподвижништву $(Ф и л ~ 1,5)$. Он до те мере говори на њихову похвалу „колико би неко рекао о Апостолима и Јеванђелистима. “50

Из реченог видимо да физичка блискост и непосредан контакт нису нужан предуслов за очување пријатељског односа јер христоцентричан живот ствара основу за трансцендирање физичких ограничења. Речју, делатна и молитвена пракса у раном хришћанству чине основу за очување блискости, чак и када су лични контакти ограничени.

\section{2. Додатак: Сведочанство химне (о) љубави (1Кор 13)}

Приметно је да доста онога што данас подразумевамо под пријатељством срећемо и код апостола Павла. Штавише, он у односе укључује неке елементе хришћанске вере, које у световном одређењу не срећемо. Ту је пре свега реч о љубави као централном аспекту хришћанског живота, који је и те како присутан код апостола Павла

46 Драгутиновић 2010, 69.

47 Теофан 2008, 108.

48 Аверкије 2005, 258.

49 Поповић 1986, 15.

50 Теофан 2008, 21. 
и који је значајан за разумевање пријатељства. У профаном одређењу пријатељства срећемо еуфемизме за љубав, као што су емотивна повезаност и сл. ${ }^{51}$ Несумњиво је да су пријатељски односи прожети љубављу, она се помиње, али се не одређује прецизније, нити се апострофира као један од најзначајнијих фактора пријатељства. Павлу је, са друге стране, љубав централна мисао и начин целокупног црквеног устројства.

У Посланици Филипљанима прототип хришћанског живота осликан је у реалном понашању историјске личности Богочовека према људима. Тачније, у христолошкој химни $^{52}$ Христов лични пример и његова љубав служи као узор људима. Он је путоказ и стремљење Филипљана, Тимотеја и Епафродита, али и самог Павла. Сличан приступ апостол има и у посланици упућеној Коринћанима. Химна љубави садржи исти концепт јер у њој Павле антропоморфизује највећи хришћански дар - љубав. Филипљанима је као узор дат Христос, а Коринћанима љубав. Реч је о персонификованој, оваплоћеној љубави, која је синоним за Бога. Као што Христос треба да прожме Филипљане, тако и љубав (Христос) треба да прожме Коринћане.

Химна је централни део ширег контекста у којем Павле тежи да стави тачку на поделе у Коринту. У тим покушајима он означава љубав најузвишенијим путем изградње јединства црквеног организма. Као прву карактеристику љубави Павле означава трпљење. Трпљење, као први „састојак“ љубави, Павле исказује на многим местима. Упечатљиво је његово обраћање када истиче да има „жељу умријети и са Христом бити“" 53 али остаје у телу да би верне подигао, што је својеврсна пријатељска жртва за читаву заједницу. Затим наставља даље и говори да је љубав благотворна, без зависти, гордости, надимања, она не чини што не пристоји, не тражи своје, ${ }^{54}$ у њој не обитава зло и неправда, радује је истина, она верује, нада се и трпи (1Кор 13, 4-7). Користећи све ове придеве, аутор жели да што јасније експлицира своју мисао и одагна сваку могућу двосмисленост и нејасноћу у разумевању.

Видимо да за Павла љубав подразумева истрајавање, дуготрпљење, подношење свих недаћа, као што је Христос поднео, као што, уосталом, и Павле подноси. Апостол Петар, позивајући се на Павла, о овоме каже „и дуготрпљење Господа нашега држите за спасење“, 55 што по оцу Јустину представља најснажније осећање и најнадахнутије изражавање Павлових речи. ${ }^{56}$ Христолика љубав хришћанима у Коринту треба да буде начин превазилажења свих подела и проблема са којима се сусрећу. Љубав је за апостола срж свих хришћанских односа. Она дакле није само ствар пријатељства, али је важна и за пријатељство јер она повезује све односе са Христовим телом и све уграђује у Христово тело.

Сведочанство химне љубави и разматрани делови Посланице Коринћанима значајни су јер употпуњују све оно што смо о хришћанском схватању пријатељства издвојили у Посланици Филипљанима. Христолошка химна и химна љубави апострифирају Христоса (љубав) као узор људима, утичући тиме и на опхођење у пријатељским односима.

51 Заједничка интересовања, жеље и идеали, узајамна наклоност, поверење и међусобна везаност и оданост, блискост, искреност и сл. представљају саставне компоненте пријатељства. ПоткоњакПијановић и др. 1996, 395.

52 Фил 2, 5-11.

53 Исто $1,23$.

54 Овде уочавамо сличност са Фил 2,4 где Павле саветује: „не старајте се свако за своје...“

55 2Птр 3, 15.

56 Поповић 2001, 229. 


\section{3. Изазов примене на часовима Верске наставе}

Блиска пријатељства јављају се између осме и девете године ${ }^{57}$ када психички развој детета напредује, због чега се млађи школски узраст сматра периодом када је дете спремно за свесну исповест, чиме започиње рад на свом унутарњем човеку. ${ }^{58}$ То је и период када дете стиче слободу, али није до краја свесно њеног смисла, услед чега се јавља опасност од удаљавања од духовности. ${ }^{59}$ Све ово указује на важност теме пријатељства, али и на потребу адекватног приступа, условљену особеностима узраста. У супротном, духовни допринос теми пријатељства може бити неадекватан или чак контрапродуктиван.

Пријатељство деца често доживљавају у контексту инструментализације другог зарад сопствених интереса. Пријатељ је неко ко треба да помаже, слуша, чини да се осећамо лепо. Свако поступање супротно од очекиваног може да стави пријатељство на тест. Са друге стране, хришћанско пријатељство је изнад егоистичних потреба, оно превазилази партикуларне интересе. Павлу је Тимотеј био потребан уз себе, али га он ипак шаље у Филипе. Тимотеју није било лако да се прихвати овог задатка, но он то ипак чини. Подједнако је упечатљив пример и Епафродит. Његова љубав и брига изнедрили су спремност на пријатељску жртву. Ови и други слични примери су веома важни јер могу допринети изградњи пријатељства међу децом које неће бити инструменталног карактера. Већ у првом разреду деца уче о човеку као бићу заједнице на микро (породичном) и макро нивоу (сви људи као део Божје породице). ${ }^{60}$ Ове и сличне тематске јединице пружају одличну могућност да ученици чују ове примере и развијају пријатељско опхођење у вршњачким односима. Из Павловог примера видимо да је у раду на „преумљењу“ најважније сведочити љубав, јер она употпуњује сва педагошка знања и омогућава да „методологијом срца“, уз поједностављене примере и аналогије, мудре басне, бајке и приче, допру до деце.$^{61}$ У том смислу веома важна потпора часовима Верске наставе јесте Црква и Евхаристија.

Посета Цркви и партиципирање у обредима представља интегрални део наставе Веронауке. У Цркви се, световним речником говорећи, поштује достојанство сваког појединца без обзира на разлике. Црква је заједница једнаких и у њој световни елементи сегрегације не важе. ${ }^{62}$ Овај вид заједничарења, односно пријатељског опхођења, чини суштинско обележје живота хришћана у свим приликама. Сагледавањем ових примера ученици могу да увиде практичну страну и историјску виталност хришћанског пријатељства. На овај начин долази до споја теоријског (учионичког) и практичног (црквеног) стицања знања, што има огроман васпитни потенцијал. Тако ученици, поучени непосредно доживљеним црквеним искуством, могу бити подстакнути да овај осећај припадности и заједништва прошире и на друге односе. Породица са атрибутом „мале Цркве“, и разредна заједница могу да буду места пројављивања хришћанских вредности.

Васпитни потенцијал Посланице Филипљанима значајан је за изградњу и очување вршњачког пријатељства утемељеног у љубави, али може бити од велике

57 Крњајић 1990, 77.

58 Скљарова 2016, 257.

59 Зењковски 2002, 131.

60 Видети: „Наставни програм Верске наставе - Православног катихизиса за основну школу од IIV разреда.“

61 Каменов 2010, 51.

62 Чак су и клирици, као пастири и вође, само први међу једнакима. Свештенство подразумева пре свега служење (Богу и верном народу), а неки јерархијски степени и етимолошки упућују на то

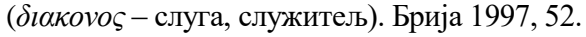


користи и када је реч о односима деце и одраслих. Дете поласком у школу више није прихваћено per se, већ од постигнућа зависи омиљеност од стране вршњака и ближе околине, а то може бити извор фрустрација и бунта, како према ауторитету наставника тако и према родитељима. Однос Павла и Филипљана може бити тумачен у циљу разумевања и превазилажења ових тешкоћа. Павле када саветује и када упути прекор, то чини из љубави и жеље да друге учини бољим. За Тимотеја је слање у Филипе био велики напор, у световним категоријама тумачено то је чак и казна. Исти је случај и када је реч о послању Епафродита из Филипа ка Павлу. Међутим, они то прихватају без роптања, свесни да је то на корист њих и њихових пријатеља. Одређени задаци, обавезе и прекори које деца добијају од родитеља и наставника нису нужно лоши. Ако су резултат бриге и љубави и уколико не вређају достојанство детета, онда је од њих велика корист. Прављење овакве аналогије учи децу да критика, па чак и одређења „казна“, може бити кориснија од неутемељене похвале. Она је корисна и пожељна у истинском пријатељству, које је базирано на љубави. Са друге стране, одрасле подсећа да су дужни да љубе васпитанике као што Павле чини и као што наводи у химни љубави. Таква врста односа мора постојати у односу родитељ-дете, а преко је потребно у односу наставник-ученик. Одрасли могу бити схваћени не као строги ауторитети, већ као сарадници (пријатељи) који нас љубављу усмеравају ка једином истинском ауторитету. Циљ оваквог усмеравања је у световном схватању свестрани (иеловит) развој личности, док је за хришћане овакво стремљење оличено у термину обожење и оно представља смисао живота за верујуће.

Напослетку, значај Посланице Филипљанима огледа се и кроз могући допринос развоју ширег спектра социјалних вештина. У савременом свету су развој толеранције, децентрације, бриге за осећања другог и емпатија преко потребни, али и често дефицитарни људски квалитети. Поменуте вештине такође су део васпитних циљеви школе. ${ }^{63}$ Хришћански примери пријатељства у Посланици Филипљанима садрже све наведене карактеристике личности, тако да се допринос ове теме на часовима Верске наставе огледа и у остваривању васпитних циљева школе.

\section{Закључак}

Посланица Филипљанима садржи многа места која, у контексту пријатељства, могу бити предмет тумачења, а ми смо се ограничили на нека која сматрамо важним. Текст посланице нам пружа увид у живот ране Цркве и односе које су хришћани међусобно градили. Ти односи су утемељени у љубави према Богу и манифестовани у љубљењу сваког човека као иконе живог Бога. Овај вид односа изграђен је у рано доба хришћанства, а присутан је међу хришћанима све до данас.

Тема пријатељства тематски и развојно одговара деци школског узраста, због чега је важно бавити се њом на часовима Верске наставе. На тај начин се може допринети изградњи трајнијег и искренијег пријатељства, посебно ако се узме у обзир специфичност хришћанског гледања на све међуљудске односе. Наравно, значајно је пружити деци и практичне увиде у хришћанско пријатељство кроз лично деловање и литургијско сабрање. Сакралност црквеног простора и сусрет са Богом могу, у корелацији са педагошким радом у школи, обогатити и употпунити другарске односе и омогућити достизање пуноће хришћанског живота.

63 У циљеве основног образовања спадају: развој способности за тимски рад (чл. 21/10), развој солидарности и сарадње (чл. 21/12), као и развој толеранције и поштовање различитости (чл. 21/15). Видети: Закон о основном образовању и васпитању. 


\section{Извори}

Nestle, Eberhart-Aland, Barbara (et al.) (2006): Novum Testamentum Graece. Stuttgart: Deutsche Bibelgesellschaft 27.

Свети Архијерејски Синод СПЦ (прир.) (2012): Нови Завјет. Београд: Библијско друштво Србије.

\section{Литература}

Аверкије (2005): Приручник за изучавање Светог Писма Новог Завета. Део 2, Апостол. Краљево: Епархијски управни одбор Епархије жичке.

Aristotel (1988): Nikomahova etika. Zagreb: Globus. Са старогрчког превео Томислав Ладан.

Berry, L. Ken (1996): "The Function of Friendship Language in Philippians 4: 10-20," in John T. Fitzgerald (ed.) Friendship, flattery, and frankness of speech. Leiden - New York Koln: Brill.

Брија, Јован (1997): Речник православне теологије. Београд: Хиландарски фонд Богословског факултета СПЦ.

Briones, E. David (2019): "Paul's Theology of Friendship,” приступљено 14.3.2020, https://faculty.wts.edu/posts/pauls-theology-of-friendship/.

Goshen-Gottstein, Alon (2020): "Understanding Jewish Friendship, Extending Friendship Beyond Judaism," приступљено 10.4.2020, http://elijah-interfaith.org/sharingwisdom/understanding-jewish-friendship-extending-friendship-beyond-judaism .

De Silva, A. David (2017): „We are Debtors, “: Grace and Obligation in Paul and Seneca, “ in Dodson, Joey-Briones, David (ed.) Paul and Seneca in Dialogue. Leiden - Boston: Brill.

Драгутиновић, Предраг (2010): Увод у нови завет: основи новозаветне науке 1. Београд: Институт за теолошка истраживања. 302.

Драгутиновић, Предраг (2011): „Нови завет и философија,“ Саборност 5, 297 -

Дрејн, Џон (2004): Увођење у Нови завет. Београд: Clio.

Закон о основном образоваьу и васпитағу, приступљено 20.4.2020, http://www.mpn.gov.rs/dokumenta-i-propisi/zakonski-okvir/ .

Зењковски, Василиј (2002): Проблеми васпитања у светлу хришћанске антропологије. Београд: Бримо.

Johnson, Luke Timothy (2004): Brother of Jesus, Friend of God: Studies in the Letter of James. Grand Rapids, MI-Cambridge: Eerdmans.

Каменов, Емил (2010): Методика наставе веронауке. Београд: Православно богословски факултет и Педагошко-катихетски институт.

Каравидопулос, Д. Јоанис (2009): Увод у Нови завет. Београд - Шибеник: Истина.

Крњајић, Стеван (1990): Дечја пријатељства. Београд: Просвета.

Martin, Ralph (1991): Pavlova poslanica Filipljanima. London: The Tyndale Press.

Martin, P. Ralph (1980): The new century Bible commentary: Philippians. Grand Rapids: Marshall, Morgan\&Scott.

„Наставни програм Верске наставе - Православног катихизиса за основну школу

од I-IV разреда“ приступљено 18.04.2020 http://eparhija-zicka.rs/novi-nastavni-planprogram-verske-nastave-pravoslavnog-katihizisa/ .

Поповић, Јустин (1986): Тумачење Посланица Филипљанима и Колошанима. Београд: Манастир Ћелије. 
Поповић, Јустин (2001): Тумачење Посланица прве и друге Коринћанима Светог апостола Павла. Београд: Манастир Ћелије.

Поткоњак, Никола-Пијановић, Петар (et al.) (1996): Педагошки лексикон. Београд: Завод за уџбенике.

Reumann, John (1996): "Philippians, Especially Chapter 4, as a "Letter of Friendship": Observations on a Checkered History of Scholarship," in John T. Fitzgerald (ed.) Friendship, flattery, and frankness of speech. Leiden - New York - Koln: Brill.

Савковић, Фива (2019): „Философски концепти и дидактичке методе римских стоика у Посланици Римљанима,“"Богословље, бр. 2, 5-22.

Скљарова, Татјана (2016): Развојна психологија и педагогија за наставнике $и$ родитеље. Београд: Православни богословски факултет - Педагошко-катихетски институт.

Теодосић, Радован (1967): Педагошки речник 1. том. Београд: Завод за издавање уџбеника социјалистичке Републике Србије.

Теофан, Затворник (2008): Тумачење Посланице светог апостола Павла Филипьанима; Тумачење Посланице светог апостола Павла Филимону. Крагујевац: Каленић.

Теофан, Затворник (2015): Тумачење Прве посланице светог апостола Павла Коринћанима. Крагујевац: Каленић.

Haacker, Klaus (2003): "Paul's life," in James, D. G. Dunn (ed.) The Cambridge companion to st. Paul. New York: Cambridge university press. Publishing.

Hansen, Walter (2009): The letter to the Philippians. Grand Rapids: Wm. B. Eerdmans

Hartog, Paul (2010): "Philippians," in David E. Aune (ed.) The Blackwell Companion to the New Testament. Malden - Oxford: Blackwell Publishing.

Hawthorne F. Gerald-Martin P. Ralph (2004): Word Biblical Commentary, Volume 43: Philippians (Revised and Expanded). New York: Thomas Nelson.

Hellerman, Joseph (2009): „Brothers and Friends in Philippi: Family Honor in the Roman World and in Paul's Letter to the Philippians," Biblical Theology Bulletin 39, no. 1, 1525.

Winter, Sean (2016): "Friendship traditions in the New Testament: An overview," Pacifica: Australasian Theological Studies 29, no. 2, 192-204. 


\section{Marko Trajković}

\section{CHRISTIAN FRIENDSHIP IN THE EPISTLE TO THE PHILIPPIANS AND POSSIBILITIES OF PEDAGOGICAL APPLICATION IN RELIGIOUS EDUCATION CLASSES}

In this paper, the author examines the Christian understanding of friendship based on the example of the Apostle Paul's Epistle to the Philippians. Paul does not use the term friendship in his writings, but his relationship with Christians in Philippi is very friendly. Their relationship transcends friendship in the classical sense and therefore that relationship is much stronger because it is based on love for God. Besides the Epistle to the Philippians, the analyzed part of the Epistle to the Corinthians supports this statement. Further in the paper, we will point out the possibilities of pedagogical application of the Christian concept of friendship in the Religious education classes. Friendship is an important topic for school-age children and the particular understanding of friendship in Christianity imposes the need to deal with this topic in Religious education. 